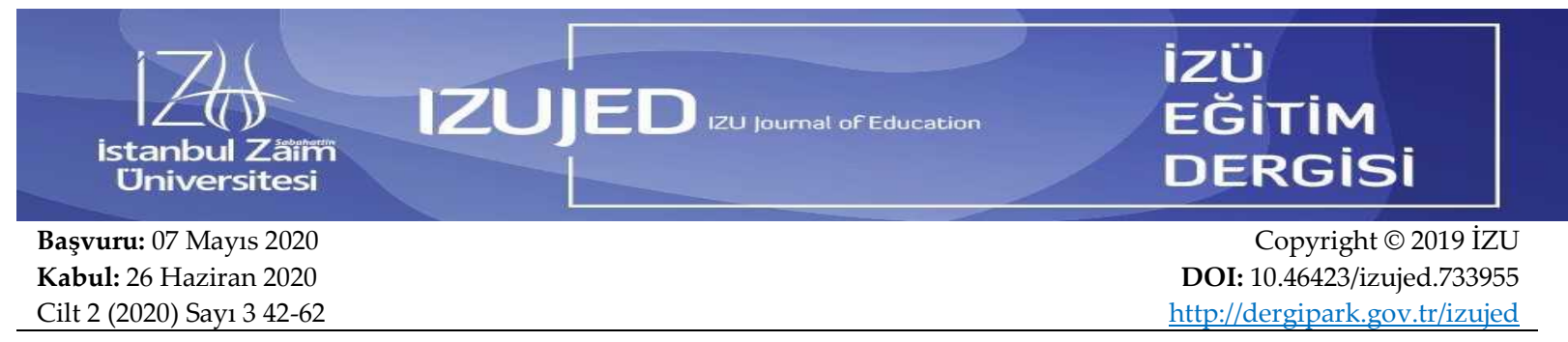

\title{
Okul Yöneticilerinin Kriz Yönetimi Tutumları ile Duygusal Zekâları Arasındaki İlişki ${ }^{1}$
}

İlker YILMAZ ${ }^{2}$
Bilal YILDIRIM ${ }^{3}$

Öz

Bu çalışmanın amacl, okul yöneticilerinin görüşlerine göre, yöneticilerin kriz yönetimi becerileri ile duygusal zekâ düzeyleri arasındaki ilişkinin belirlenebilmesidir. Bu araştırmanın evrenini, 2016-2017 yıllarındakiİstanbul'daki Avcılar ve Esenyurt ilçelerindeki okullarda görevli toplam 539 okul yöneticisi oluşturmaktadır. Evren ulaşılabilir olduğu için örnekleme yapılmamış, ölçekler tüm evrene ulaştırılmıştır. Toplam 466 ölçek değerlendirmeye alınmıştır. Veriler Kriz yönetimi Ölçeği ve “Duygusal Zekâ Ölçeği" ile toplanmıştır.

Verilere ilişkin normallik testi sonucunda dağılım normallik göstermemiş bu nedenle non-paremetrik testlerden Mann Whitney U testi, Kruskal Wallis testi ve Spearman's Rank Order korelasyon testi kullanılmıştır. Genel olarak araştırma sonuçlarından yöneticilerin duygusal zekâ düzeylerinde cinsiyete ve yaşa göre anlamlı farklılaşma; kriz yönetimi düzeylerinde ise cinsiyete, yöneticilik görevlerine, yaşa ve okul türüne göre anlamlı farklılaşma belirlenmiştir. Yöneticilerin duygusal zekâ ve kriz yönetimi düzeyleri arasında anlamlı bir ilişki bulunmuştur. Duygusal zekâ alt ölçeklerinden iyimserlik ölçeği puanları ile kriz yönetimi alt ölçeklerinden kriz anı ve kriz sonrası ölçek puanları arasında pozitif yönde ilişkiler bulunmuştur. Duygusal zekâ alt ölçeklerinden duygulardan faydalanma ölçeği puanları ile kriz yönetimi alt ölçeklerinden kriz öncesi ve kriz sonrası ölçek puanları arasında düşük ancak anlamlı düzeyde ilişkiler bulunmuştur. Duygusal zekâ alt ölçeklerinden duyguların ifadesi ölçeği puanları ile kriz yönetimi alt ölçeklerinden kriz öncesi ölçek puanları arasında pozitif yönde anlamlı bir ilişki bulunmuştur. Bu bulgulara göre, duyguların anlamlı biçimde ifade edilmesi kriz öncesi belirtilerin ve olası etkilerinin neler olabileceğinin paylaşılmasında ve gerekli önlemlerin alınmasında önemli bir durum olarak ifade edilebilir. Okul yöneticilerinin seçiminde duygusal zekâsı gelişmiş olanlara öncelik verilmesi kriz yönetimi açısından yararlı olabilir.

Anahtar kelimeler: Okul yöneticisi, krizi yönetimi, duygusal zekâ

\section{The Relationship Between The Managers' Crisis Management Skills and Emotional İntelligence Levels}

\begin{abstract}
The aim of this study is to determine the relationship between managers' crisis management skills and emotional intelligence levels according to the opinions of school administrators. The universe of this research consists of 539 school administrators working in schools in Avclar and Esenyurt districts in Istanbul in 2016-2017. As the universe is accessible, nosampling was performed and the scales were delivered to the entire universe. However, 73 of them were not evaluateddue to incorrect or

\footnotetext{
${ }^{1}$ Bu çalışma, İlker Yılmaz'ın, Doç.Dr. Bilal Yıldırım danışmanlığında İstanbul Sabahattin Zaim Üniversitesi Sosyal Bilimler Enstitüsünde yaptığı lisansüstü teze dayalı olarak hazırlanmıştır.

2 Öğretmen, Milli Eğitim Bakanlığı, İstanbul, Turkiye, e-mail: ilkerveyilmaz@gmail.com

${ }^{3}$ Sorumlu Yazar: Doç. Dr. İstanbul Sabahattin Zaim Üniversitesi Eğitim Fakültesi, İstanbul, Türkiye, ORCID: 00000001-6225-5859, e-mail: bilal.yildirim@izu.edu.tr, Atıf: Yılmaz, İ. \& Yıldırım, B. (2020). Okul yöneticilerinin kriz yönetimi tutumları ile duygusal zekâları arasındaki ilişki, İZü Ĕ̆itim Dergisi 2(3) 42-62.
} 
incompletefilling. A total of 466 scales were evaluated. Data were collected with Crisis Management Scale and Emotional Intelligence Scale.

SPSS 23 package was used for data analysis. As a result of the normality test, the distribution was not normal, so Mann-Whitney U test, Kruskal Wallis test and Spearman's Rank Order correlation test were used. In general, it was observed that the level of emotional intelligence optimism of the managers was high and they were successful in the post-crisis management level. In general, according to the results of the research, managers' emotional intelligence levels differ significantly according to gender and age; and in the crisis management levels, significant differences were determined according to gender, administrative duties, age and type of school. There was a significant relationship between managers' emotional intelligence and crisis management levels. Positive correlation was found between the optimism scale scores of the emotional intelligence subscales and the moment of crisis and post-crisis scale scores of the crisis management subscales. There was a low but significant relationship between emotional intelligence subscale scores and the pre-crisis and post-crisis scale scores of the crisis management subscales. A positive correlation was found between the scores of emotion expression scale and the pre-crisis scale scores of the crisis management subscales.

Key words: School manager, crisis management, emotional intelligence

\section{Extended Abstract}

\section{Introduction}

It is up to the school principal to be prepared for the crisis situations of the school and to take the necessary security measures at the school. Managers, who are at the highest level in ensuring crisis management, are the most wanted people in times of crisis (Sayın, 2008: 5). Therefore, in educational institutions managed by school administrators who do not have sufficient crisis management skills, crises will bring negative results.

The only way to provide the desired confidence and peace environment; It is through recognizing crisis signals, analyzing school general situation, preparing crisis scenarios, creating crisis plans, conducting exercises about scenarios that may occur, keeping crisis management plans up to date and creating crisis management team who know what to do (Aksoy \& Aksoy, 2003; Asunakutlu et al. 2003; Karaköse, 2007; Ulutaş, 2010).

The concept of "emotional intelligence" as a concept is "a person's awareness of both his own feelings and his feelings, understanding, describing them, associating them with resources and causes, managing their emotions and using them effectively both in personal and interpersonal relations" awareness "," empathy "," emotion management "and" relationship management "combine personal and social competencies (Güllüce, 2006: 40).

Researches show that emotional intelligence is very important in relationships between people (Alparslan \& Çetinkaya, 2011). Schools are organizations that remain open for most of the day, actively work, and where an environment of trust and peace is required, and relationships between people are intense. For this reason, effective school administrators should be people who can take full responsibility for the functioning of educational organizations, have vision, care about the thoughts of the people around them, have the ability to lead schools and are not afraid of change. Emotional intelligence stands out as the most important feature that distinguishes effective school administrators from others (Öztekin, 2006).

Emotional intelligence is one of the most important requirements of effective school management. Managers should be able to recognize and manage the emotional transitions 
experienced within the institution they work in, and make it compulsory to use it as a remarkable management tool (Arbak \& Çakar, 2004: 44).

The findings obtained from the research will provide an important resource for studies and training to be conducted in order to be a resource for the studies to be carried out with regard to crisis management attitudes and emotional intelligence, to determine the crisis management attitudes and emotional intelligence levels of school administrators, and to improve the knowledge and skills of school administrators about the concept of crisis management. It is hoped that school administrators can help to measure the impact of emotional intelligence on crisis management attitudes, shedding light on general research on topics, and in short, examining school administrators' crisis management attitudes and their relationship with emotional intelligence will be beneficial for the development of educational programs.

The purpose of the research on these reasons is that, according to the opinions of the school administrators; is the determination of the relationship between managers' crisis management skills and emotional intelligence levels. For this purpose, answers to the following questions were sought:

1. What are the Emotional Intelligence and Crisis Management levels of school administrators?

2. Do the Emotional Intelligence and Crisis Management levels of the school administrators differ according to gender, administrative duties, age, seniority and education level?

3. Is there a significant relationship between Emotional Intelligence and Crisis Management levels of school administrators?

\section{Method}

The research is a relational screening model since the relationship between school administrators' crisis management attitudes and emotional intelligence is examined. Relational scanning model; It is a research model that aims to predict possible results by determining the connections between many variables and to determine the stage between them by looking at correlation (Karasar, 2006: 81).

The universe of the study is 539 school administrators in Avcllar and Esenyurt districts of Istanbul between 2016-2017. Scales were delivered to the entire working universe, which was not sampled, and all of them returned. However, it was not evaluated because 73 of them were filled incorrectly or incompletely. A total of 466 scales were evaluated.

\section{Findings and Discussion}

"Do the Emotional Intelligence and Crisis Management levels of school administrators differ according to gender, management duties, age, seniority and school type?" According to the results of the analysis related to the second sub-problem of the question, the scores of "Optimism Scale", which are among the Emotional Intelligence subscales of school administrators, differ significantly according to the gender variable. Accordingly, when their averages are taken into consideration, it is seen that the scores of female managers are higher than the male managers. Optimism is higher in women than men; It can be interpreted in the sense that women can empathize, think optimistically, and recognize positive and negative situations more comfortably than men. Looking at the studies, there are many studies showing that emotional intelligence dimensions of women such as Mayer, Caruso, Salovey (1999), 
Caputi, Chan, Ciarrochi (2000), Göçet (2006) are higher than men. Also in the literature, when Bar-on et al. (2000), Akeren (2006), Babaoğlan (2010) investigates his research, there are different studies that say there is no difference between emotional intelligence dimensions between female managers and male managers. The sub-scores of the Emotional Intelligence subscales of school administrators did not differ significantly according to the variable of managerial task. Babaoğlan (2010) supports this result in his research. The scores of School Administrators' Emotional Intelligence Scale, which is one of the Emotional Intelligence subscales, show significant differences according to the age variable. Accordingly, it was concluded that school administrators aged 51 and over had higher scores on emotion-benefit scale than those aged 20-30. With this result, as the age gets older, the negative feelings and motives that the manager has made easier for them to be aware of the new possibilities in the school according to their colleagues who are new to the profession, that they know the feelings of the staff they work with, and that they can live by recognizing their own feelings, are more comfortable under control can be interpreted as holding. Mayer, Caruso, Salovey (1999), Baron et al. (2000) concluded that emotional intelligence will increase with age as their studies increase. Akeren (2006) and Babaoğlan (2010) did not find any difference in the emotional intelligence sub-scales of managers according to the age variable.

The sub-scores of the Emotional Intelligence subscales of school administrators did not differ significantly according to the professional seniority variable. Akeren (2006) did not find any difference in the emotional intelligence subscales of managers according to the variable of seniority. The sub-scores of the Emotional Intelligence subscales of the school administrators did not differ significantly according to the education level variable. Babaoğlan (2010) found the emotional intelligence scores of the administrators in primary schools higher than the administrators in secondary schools according to the education level variable in emotional intelligence subscales. "Moment of Crisis Scale" scores of school administrators' crisis management subscales show significant differences according to gender. Accordingly, considering the averages of women managers, crisis moment scale scores are higher than male managers. It can be interpreted that female managers' high score of crisis moment scale is higher than male managers, female managers are ready for a crisis that can be experienced at any time and they are ready for management in crisis moment. In her research, Şahin (2014) found female teachers' perception of crisis management higher than male teachers. According to gender variable, Özsezer (2014) found that school administrators' crisis management skills were significantly sufficient in terms of "moment of crisis" and "after crisis" compared to women. Maya (2014), Ulutaş (2010), Wheeler (2002, Act. January, 2006) did not find a significant difference by gender in the crisis management subscales of managers.

The "Pre-Crisis Scale" scores of the school administrators' Crisis management subscales show significant differences according to the managerial task variable. Accordingly, when the averages are taken into consideration, the scores of the principals before the crisis are higher than the assistants of the director. This shows that school principals are more successful than deputy principals in crisis management before the crisis and they feel responsible for making necessary preparations for crisis management. Sayın (2008), in his study, a similar difference was found according to the variable of managerial duty.

The "Crisis Moment Scale" scores, which are among the crisis management sub-scales of school administrators, show significant differences according to the age variable of the administrators. Accordingly, when the findings are analyzed, school administrators aged 51 
and over perform their crisis management more successfully in the crisis when compared to those aged 31-40. This result can be interpreted as the experienced school administrators take control of the crisis by taking advantage of their own experience in crisis management. Sayin (2008), Yildiz (2014) obtained the results of increasing management skills of the managers as their age increases. Şahin (2014), teachers between the ages of 41-45 are more likely to think about crisis management than teachers between the ages of 22-30, 36-40 and 31-35. Wheeler (2002, Akt. January, 2006), Ulutaş (2010) did not find a significant difference in school administrators' crisis management subscales according to age variable. Subscores of the crisis management sub-scales of school administrators did not differ significantly according to the professional seniority variable. Wheeler (2002, Akt. January, 2006) did not find a significant difference in school administrators' crisis management subscales according to the professional seniority variable. The "Post-Crisis Scale" scores of the school administrators' Crisis management subscales differ significantly according to the education level variable. They are the main responsible for providing the necessary confidence and peace environment in the school environment, so it can be interpreted as an expected situation that they have the necessary experience in the improvement and learning steps to be carried out after the crisis.

"Is there a significant relationship between the emotional Intelligence and Crisis Management levels of school administrators?" According to the results of the analysis related to the third sub-problem of the problem, positive correlations were found between the scores of the school administrators' emotional intelligence subscales of optimism scale and the crisis management subscales of the crisis moment and post-crisis management subscale scores. Accordingly, as the school administrators' optimism scores increase, the moment of crisis and the post-crisis points also increase. It is an expected result that the level of optimism will be high in terms of eliminating the negativities that may occur after the crisis and after the crisis, benefiting from the crisis, evaluating the crisis, and being aware of the positive and negative results. Low but significant relationships were found between school administrators' emotional intelligence subscales scores from emotional intelligence subscales and crisis management subscales before and after the crisis. Accordingly, as the scores of school administrators benefiting from emotions increase, their pre-crisis and post-crisis scores increase, albeit low. It is important to correctly perceive messages about the crisis before and after the crisis. Using the emotional and mental development of school administrators at this time, he must ensure that people in the institution are prepared for the crisis. After the crisis, it is expected to reveal the positive emotions needed to learn lessons and to benefit from the emotions of both him and the people around him.

There is a positive relationship between the emotional intelligence subscales of school administrators and the expression of emotions scale and the pre-crisis management subscale scores of the crisis management subscales. According to this, as the scores of expressions of school administrators from emotions increase, their pre-crisis scores increase. It is desirable to be informed about the crisis situations in order to get the correct communication, to predict the positive and negative situations that may arise, to recognize the emotions that may arise about the crisis and to prevent misunderstandings, to start receiving the signals of the crisis and to prevent the misunderstandings.

\section{Giriş}

Özellikle yirmibirinci yüzyılda hayatın her alanın meydana gelen hızlı değişimlere bağlı beklenmedik ve zamana bırakılmayacak kadar büyük krizler ortaya çıkabilmektedir. Gephart 
(1984), krizlerin sürekli tekraralanabilen ve önlenemez gerçekler oldmasına vurgu yaparken (Perrow, 1984), diğer bazı yazarlar (Meyers, 1986; Pauchant ve Mitroff, 1992; Pearson ve Mitroff, 1993; Roberts, 1989) örgütsel krizleri yönetme veya önlemenin yollarını belirlemeye odaklanmaktadır (Pearson \& Clair,1998).

Kriz, bir yönetim sorunudur. Oluştuğu kurumun amaçlarını tehdit edip kurumun işleyişini bozar ve acil tepkiler verilmezse kriz yönetimindeki hazırlık, korunma, önleme, çözüm, iyileştirme ve krizden dersler çıkarma aşamalarında yetersizlikler ve çözümsüzlükler oluşturabilir. Sürekli çevresiyle etkileşim halinde olan eğitim kurumlarının krizlerden en az şekilde etkilenmesi, çağa uygun önlemlerin alınmasında birinci derecede sorumlu olan eğitim yöneticileri kriz zamanlarında en çok aranan kişilerdir (Sayın, 2008: 5).

Önemli etkenlerden birisi olan okulda yaşanabilecek krizlere yönelik gerekli önlemlerin alınmadığı okul ortamlarında görevli bireylerin hedeflenen düzeyde öğrenme ve öğretme hedeflerini gerçekleştirmesi zordur. Bu yüzden yeterli kriz yönetimi becerisine sahip olmayan okul yöneticilerinin yönettiği eğitim kurumlarında krizler olumsuz sonuçlara yol açabilir.

Uygun ve etkili eğitim ortamlarının sağlanabilmesinin birçok yolu vardır. Bunların başında kriz sinyallerini tanımak, genel durum analizi yapmak, kriz senaryoları hazırlamak, yaşanabilecek durumlara yönelik hazırlanan senaryolar ile ilgili tatbikatlar yapmak ve ne yapacağını bilen kriz yönetimi ekibi oluşturmak gibi önlemler yer almaktadır (Aksoy ve Aksoy, 2003; Asunakutlu vd., 2003; Karaköse, 2007; Ulutaş, 2010).

Kriz; sadece tehlike, güvensizlik, belirsizlik, tehdit, endişe ve panik anlamı taşımaz. Kriz aynı zamanda fırsatı, fark edilebilirliği, yeni bir düzeni ve gelişmeyi de içinde barındırır. Kriz zamanları yaşanılan olayların fark edilmesi; bireylerin kendilerini tanımasını, değiştirmesini ve olgunlaşmasını sağlayıcı birtakım etkilere de sahiptir. Krizlerin yönetilebilmesinde bireylerin duygusal tepkileri ve akılcı çözümler üretebilmeleri de çok önemlidir. Zeka çevreye uyum sağlayabilme yeteneği olarak tanımlanmaktadır. Zeka başarılı davranışlar üreten yetenek olarak da tanımlanmaktadır (Albus, 1991). Zeka olaylar, durumlar ve değişimler karşısında başarılı davranışlar üretmenin ana etkeni kabul edilirse, beklenmedik durumlarda bireylerin duygularının da etkili olduğu bilgisiyle krizlerle duygusal zekanın doğrudan bir iliikisinin olduğu savunulabilir. Duygusal zeka, kişinin kendisinin ve başkalarının duygularını izleme, aralarında ayrım yapma ve bilgiye ilişkin düşünme ve eylemlerini yönlendirmede kullanma yeteneğini içeren bir tür sosyal zekadır (Salovey ve Mayer, 2004).

İnsan kendi duygularını anlayıp, yönetip, anlatabilme ihtiyacının yanında; başkalarının duygularını anlayabilme ve tanıyabilme çabasıyla hayatını sürdürmektedir. "Kişinin hem kendi duygularının hem de karşısındaki kişilerin duygularının farkında olması, onları anlaması, tanımlaması, kaynakları ve nedenleriyle ilişkilendirmesi, duygularını yönetmesi ve onlardan hem kişisel alanda hem de kişilerarası ilişkilerinde etkin bir biçimde yararlanması" kavram olarak duygusal zekânın tanımıdır ve bu tanıma bakıldığında "kişisel farkındalık", "empati", "duygu yönetimi" ve "ilişki yönetimi" gibi kişisel ve sosyal yetkinlikleri bir arada bulundurmaktadır (Güllüce, 2006: 40).

Yapılan araştırmalar duygusal zekânın, insanlar arasındaki ilişkilerde çok önemli olduğunu göstermektedir (Alparslan ve Çetinkaya, 2011). Okullar, günün büyük kısmında açık kalan, aktif şekilde çalışan, insanlar arasındaki ilişkilerin yoğun yaşandığı örgütlerdir. Bu sebeple de etkili okul yöneticileri, eğitim örgütlerindeki işleyişin tüm sorumluluğu alabilen, vizyon sahibi, etrafındaki insanların düşüncelerini önemseyen, okullara liderlik yapabilme 
yeteneğine sahip, değişimden korkmayan kişiler olabilmelidir. Etkili okul yöneticilerini diğerlerinden ayıran en önemli özellik duygusal zekâ olarak öne çıkmaktadır (Öztekin, 2006).

Yöneticilerin kendi duygularını tanıması, duygularını kontrol edebilmesi, motivasyonunu kendi başına sağlayabilmesi, başkalarının duygularını anlayabilmesi ve sosyal iletişimde başarılı olması olarak öne çıkan duygusal zekâ, etkin okul yöneticiliğinin en önemli gereklerinden birisidir. Yöneticiler, çalıştıkları kurum içinde yaşanılan duygu geçişlerini fark edebilmeli, yönetebilmeli, dikkate değer bir yönetim aracı olarak bunu kullanmayı zorunlu hale getirebilmelidir (Arbak ve Çakar, 2004: 44).

Yapılan literatür taramasındaki veriler ve çevresel gözlemlere göre, okul yöneticilerinin duygusal zekâlarının, kriz yönetimi becerilerine etkisi olduğu, başka bir ifade ile duygularını fark edebilme, onları gerektiğinde kullanabilme, sosyal ilişkileri yönetebilme kapasitesi yüksek olan okul yöneticilerinin, kriz sinyallerini anlayabilme, krize karşı hazırlıklı olma ve önlemler alabilme, kriz anında çözüm üretebilme, kriz sonrası iyileştirme, öğrenme ve değerlendirme gibi kriz yönetimi becerilerini daha olumlu etkileyeceği gerekçeleriyle okul yöneticilerinin kriz yönetimi tutumları ve duygusal zekâları arasında anlamlı düzeyde ilişki olduğu düşünülmektedir.

Yapılan literatür taraması sonucunda kriz yönetimi tutumları ile duygusal zekâ arasındaki ilişki ile ilgili doğrudan Türkçe yayınlanmış bir araştırmaya rastlanmamıştır. Araştırmadan elde edilen bulgular ile kriz yönetimi tutumları ve duygusal zekâ ile ilgili olarak yapılacak çalışmalara kaynak olması, okul yöneticilerinin kriz yönetimi tutumları ve duygusal zekâ düzeylerinin belirlenebilmesi, okul yöneticilerinin kriz yönetimi kavramıla ilgili bilgi ve yeteneklerinin geliştirilebilmesi için yapılabilecek çalışmalara ve düzenlenecek eğitimlere önemli bir kaynak sağlayacağı beklenebilir. Buna ek olarak okul yöneticilerinin kriz yönetimi tutumları ile duygusal zekâları arasındaki ilişkinin incelenmesinin, eğitim kurumlarına yönetici seçilmesinde ve eğitim kurumlarının etkili yönetilebilmesinde ipuçları sunabilmesi açısından yararlı olacağı umulmaktadır. Bu araştırmanın amacı, okul yöneticilerinin görüşlerine göre; yöneticilerin kriz yönetimi becerileri ile duygusal zekâ düzeyleri arasındaki ilişkinin belirlenebilmesidir. Bu amaçla aşağıdaki sorulara cevap aranmıştır:

1.Okul yöneticilerinin duygusal zekâ ve kriz yönetimi düzeyleri nedir?

2.Okul yöneticilerinin duygusal zekâ ve kriz yönetimi düzeyleri cinsiyete, yöneticilik görevine, yaşa, kıdeme ve görev yapılan eğitim kademesine göre farklılaşmakta mıdır?

3.Okul yöneticilerinin duygusal zekâ ve kriz yönetimi düzeyleri arasında anlamlı bir ilişki var midir?

\section{Araştırmanın Modeli}

$\mathrm{Bu}$ araştırma, okul yöneticilerinin kriz yönetimi tutumları ile duygusal zekâları arasındaki ilişki incelendiği için ilişkisel tarama modelidir. İlişkisel tarama modeli; çok sayıdaki değişkenler arasındaki bağlantıları belirleyerek, muhtemel sonuçları öngörmeyi, korelasyona bakarak aralarındaki aşamayı tayin etmeyi hedefleyen bir araştırma modellidir (Karasar, 2006: 81).

\section{Evren ve Örneklem}

Bu araştırmanın çalışma evrenini, 2016-2017 yıllarında İstanbul ili Avcılar ve Esenyurt ilçelerindeki toplam 539 okul yöneticisidir. Evren ulaşılabilir olduğu için örnekleme 
yapılmamış tüm evrene ulaşılmıştır.

Tablo 1. Okul Yöneticilerinin Cinsiyet ve Okul Türüne Göre Frekans ve Yüzdelikleri

\begin{tabular}{|c|c|c|c|c|c|c|c|c|c|c|}
\hline \multirow{3}{*}{ Okul Türü } & \multicolumn{4}{|c|}{ Evren } & \multicolumn{5}{|c|}{ Örneklem } & \multirow{3}{*}{ Toplam } \\
\hline & \multicolumn{2}{|c|}{ Kadın } & \multicolumn{2}{|c|}{ Erkek } & \multirow{2}{*}{ Toplam } & \multicolumn{2}{|c|}{ Kadın } & \multicolumn{2}{|c|}{ Erkek } & \\
\hline & $\mathrm{N}$ & $\%$ & $\mathrm{~N}$ & $\%$ & & $\mathrm{~N}$ & $\%$ & $\mathrm{~N}$ & $\%$ & \\
\hline İlkokul & 36 & 19 & 149 & 81 & 185 & 35 & 22 & 126 & 78 & 161 \\
\hline Ortaokul & 47 & 23 & 159 & 77 & 206 & 41 & 24 & 127 & 76 & 168 \\
\hline Lise & 41 & 28 & 107 & 72 & 148 & 35 & 26 & 102 & 74 & 137 \\
\hline Toplam & 124 & 23 & 415 & 77 & 539 & 111 & 24 & 355 & 76 & 466 \\
\hline
\end{tabular}

Tablo 1'de görüldüğü gibi evrene alınan okul yöneticilerinin \%23'ü kadın \%77'si erkektir. Örnekleme alınan okul yöneticilerinin \%24'ü kadın \%76'sı erkek'tir.

Okul Yöneticilerinin yöneticilik görevi ile mesleki kıdeminin frekans ve yüzdeliklerine göre dağılımı Tablo 2' deki gibidir.

Tablo 2. Okul Yöneticilerinin Yöneticilik Görevi ve Mesleki Kıdeme Göre Frekans ve Yüzdelikleri

\begin{tabular}{|c|c|c|c|c|c|}
\hline \multirow[t]{3}{*}{ Mesleki Kıdem (Y1l) } & \multicolumn{4}{|c|}{ Yöneticilik Görevi } & \multirow{3}{*}{ Toplam } \\
\hline & \multicolumn{2}{|c|}{ Müdür } & \multicolumn{2}{|c|}{ Müdür Yardımcısı } & \\
\hline & $\mathrm{N}$ & $\%$ & $\mathrm{~N}$ & $\%$ & \\
\hline $0-5$ & 2 & 5 & 34 & 95 & 36 \\
\hline 6-10 & 10 & 10 & 88 & 90 & 98 \\
\hline $11-15$ & 22 & 17 & 108 & 83 & 130 \\
\hline $16-20$ & 35 & 34 & 69 & 66 & 104 \\
\hline 21 ve üstü & 40 & 41 & 58 & 59 & 98 \\
\hline Toplam & 109 & 23 & 357 & 77 & 466 \\
\hline
\end{tabular}

Tablo 2'de görüldüğü gibi yöneticilerin \%23'ü müdür olarak görev yaparken \%77'si müdür yardımcısı olarak görev yapmaktadır.

Örneklem grubunda yer okullarda görev yapan yöneticilerin eğitim kademelerine ve yöneticilik görevlerine göre dağılımı Tablo 3'teki gibidir.

Tablo 3. Yöneticilerin Eğitim Kademelerine Ve Yöneticilik Görevlerine Göre Dağılımı

\begin{tabular}{|c|c|c|c|}
\hline & Müdür & Müdür Yardımcısı & Toplam \\
\hline \multicolumn{4}{|c|}{ Avcılar İlçesi } \\
\hline İlkokul & 32 & 91 & 123 \\
\hline Ortaokul & 30 & 114 & 144 \\
\hline Lise & 17 & 59 & 76 \\
\hline İlçe Toplamı & 79 & 264 & 343 \\
\hline \multicolumn{4}{|c|}{ Esenyurt İlçesi } \\
\hline İlkokul & 16 & 46 & 62 \\
\hline Ortaokul & 17 & 45 & 62 \\
\hline Lise & 16 & 56 & 72 \\
\hline İlçe Toplamı & 49 & 147 & 196 \\
\hline Genel Toplam & 128 & 411 & 539 \\
\hline
\end{tabular}


Bazı okullarda müdür kadrosu bulunmamaktadır. Bunun sebebi olarak aynı bahçede bulunan 2 tür okula (İlkokul-Ortaokul, Ortaokul-Lise) tek bir müdür kadrosu verilmiş olmasıdır.

\section{Verilerin Toplanması}

Veriler Kriz yönetimi Ölçeği ve Duygusal Zekâ ölçeği ile toplanmıştır. Örnekleme yapılmamış olan çalışma evreninin tamamına ölçekler ulaştırılmış tamamı geri dönmüştür. Ancak 73 tanesinin hatalı ya da eksik doldurulmuş olması sebebiyle değerlendirmeye alınmamıştır. Toplam 466 ölçek değerlendirmeye alınmıştır.

Kriz yönetimi Ölçeği: Kriz yönetimiyle ilgili okul yöneticilerinin tutumlarını ortaya koymak amacıyla Çetin ve Sayın (2008) tarafından geliştirilen ölçek 72 maddeden oluşmaktadır. Kriz öncesi, kriz anı ve kriz sonrası olmak üzere üç alt boyut vardır. Ölçek (1) hiçbir zaman, (2) çok nadir, (3)ara sıra, (4) çoğu zaman, (5) her zaman şeklinde 5'li likert tipi bir derecelendirmeye sahiptir. Ölçeğin Kaiser-Meyer-Olkin (KMO) .88 olarak hesaplanırmıştır. Her bir alt faktörün güvenirlik çalışması için Cronbach değerleri hesaplanmış ve .49 ile .79 arasında değiştiği gözlenmiştir.

Kriz yönetimi alt ölçeklerinin güvenirlik değerleri bu araştırmada yer alan örneklem gruplarından alınan puanlara göre yeniden hesaplanmış ve Cronbach değerleri kriz öncesi alt ölçeği için. .48, kriz esnası için. .69, kriz sonrası için de .77 olarak hesaplanmıştır.

Duygusal Zekâ Ölçeği: Araştırmada kullanılan Duygusal Zekâ Ölçeği, Schutte ve ark. (1998) tarafından geliştirilmiş, Austin ve ark. (2004) tarafından düzenlenmiş, Türkçe 'ye Göçet (2006) tarafından çevrilen, 37 maddeden oluşan, temeli 3 boyutlu duygusal zekâ modeline dayanmaktadır (Mayer ve Salovey, 1990). Austin ve ark. (2004) tarafından düzenlenen duygusal zekâ ölçeğinde 20 olumlu, 21 olumsuz toplam 41 madde bulunmaktadır. Kesinlikle katılmıyorum (1), katılmıyorum (2), kararsızım (3), katılıyorum (4) ve kesinlikle katılıyorum (5) şeklinde 5'li likert tipi bir derecelendirmeye sahiptir. İyimserlik / Ruh Halini Düzenleme, Duygulardan Faydalanma ve Duyguların İfadesi içeren üç faktörden oluşan ölçek ayrıca genel duygusal zekâyı da ölçmektedir.

Ölçeğin faktör analizi ile yapı geçerliliğine Göçet (2006) tarafından bakılmış, maddeler arasında faktör analizinin yapılmasına uygun nitelikte korelasyon ilişkileri bulunmuştur. KMO örneklem uygunluk katsayısı .79 olarak bulunmuştur. Barlett Sphericity testi x2 değeri 2995.55 ( p<.001) bulunmuştur. İlk faktör analizinde döngüsüz madde kullanılarak faktör çözümlemesi ile maksimum faktör sayısı karşılaştırılırmıştır. Envanter tek faktörlü bulunmuştur. Tekrar yapılan faktör analizinde ise temel bileşenler tekniği ile oblique rotasyon faktör çözümlemesi sonuçları üç faktörlülükle sınırlandırılmıştır. Bunun sonucu olarak toplam varyansın \%60'ını oluşturan üç faktörlü bir yapı meydana çıkmıştır. Birinci faktör olarak "İyimserlik" alt ölçeğine ait madde faktör yükleri .37 ile .63 arasındadır. Birinci faktör 17 maddeden oluşur ve ölçeğin varyansının \%14'ünüaçıklamaktadır. İkinci faktör "Duygulardan faydalanma" olup 6 maddeden oluşur. "Duygulardan faydalanma" alt ölçeğine ait madde faktör yükleri. 30 ile .57 arasındadır. İkinci faktör ölçeğin varyansının \%20.4'ünü açıklamaktadır. Üçüncü faktörde "Duyguların ifadesi" olarak ele alınmıştır. "Duyguların ifadesi" alt ölçeğine ait maddelerin faktör yükleri .32 ile .61 arasında değişmektedir. Üçüncü faktör 14 maddeden oluşur ve ölçeğin varyansının \%25.9'unu açıklamaktadır. 
Tablo 4. Duygusal Zekâ Ölçeğinin Alt Boyutları

\begin{tabular}{ll}
\hline 1.İyimserlik & 2-5-7-9-11-12-15-18-19-21-27-29-30-32-33-37-38 \\
2.Duygulardan Faydalanma & $4-10-20-23-25-34$ \\
3.Duyguların İfadesi & $1-6-8-17-22-24-26-28-31-35-36-39-40-41$ \\
\hline
\end{tabular}

"Bu üç faktörden herhangi birine katkı sağlamadığ görülen maddeler uyarlanan ölçekte yer almamıştır. Bu maddeler 3, 13, 14 ve 16. maddelerdir. Yapı geçerliği çalışmasında faktör yapısının yanında alt ölçekler incelenerek, aralarında Pearson Momentler Çarpımı korelasyonlarına bakılmıştır" (Göçet, 2006: 71). Bu araştırmada kullanılan duygusal zekâ ölçeğinde 19 olumlu $(1,2,4,6,8,10,12,14,15,17,23,25,26,27,28,29,32,33,34), 18$ olumsuz $(3,5,7,9,11,13,16,18,19,20,21,22,24,30,31,35,36,37)$ toplam 37 madde bulunmaktadır.

Duygusal zekâ ölçeğinin Cronbach Alpha $(\alpha)$, iç tutarlılık katsayıları ölçeğin tamamı için .81 , iyimserlik faktörü için .77, duyguların ifadesi için .73 ve duygulardan faydalanma faktörü için .54 olarak elde edilmiştir. İki yarı güvenirliğinde ise İyimserlik .71, Duyguların ifadesi .72 ve Duygulardan Faydalanma .52 olarak elde edilmiştir. Ölçeğin bütünü için ise .78 olarak bulunmuştur. Ölçeğin test-tekrar test güvenirlik seviyesini belirlemek amaciyla uygulamalardan elde edilen verilerin korelasyonun hesaplanması sonucu .63 olduğu görülmüştür (Göçet, 2006: 73). Bu çalışmada duygusal zekâ ölçeğinin uygulanması ile bulunan puanların Cronbach Alpha güvenirlik değerleri yeniden hesaplaması yapılmış, duyguların ifadesi alt ölçeğinin .77, duygulardan faydalanma .57 ve iyimserlik alt ölçeği için de .78 olarak hesaplanmıştır.

\section{Verilerin Analizi}

Araştırmada kullanılan ölçme araçlarından elde edilen puanların normallik testi için Kolmogorov Smirnov testi yapılmış, duygusal zeka puanı .074, kriz yönetimi puanı .046 olarak bulunmuştur. Elde edilen puanların. .05 'ten küçük olmasından dolayı dağılım normallik göstermemiş bu nedenle non-paremetrik testler kullanılmıştır. Okul yöneticilerinin duygusal zekâ ve kriz yönetimi tutumları alt ölçek puanlarının cinsiyete ve yöneticilik görevine göre iki grup ortalamaları arasındaki farkın anlamlılığını test etmek için Mann Whitney U testi uygulanmıştır.

Okul yöneticilerinin duygusal zekâ ve kriz yönetimi tutumları alt ölçek puanlarının yaşa, kıdemeve eğitim kademesine göre ikiden fazla grup ortalamaları arasındaki farkın anlamlığı için Kruskal Wallis testi uygulanmıştır. Okul yöneticilerinin duygusal zekâ ve kriz yönetimi tutumları alt ölçek puanlarının yaşa, kıdeme ve eğitim kademesine göre gruplar arasındaki farkın hangi gruplar arasında olduğunu tespit etmek için yine Mann Whitney U testi yapılmıştır.

Son olarak okul yöneticilerinin duygusal zekâ ve kriz yönetimi tutumları alt ölçek puanları arasında anlamlı ilişki olup olmadığını belirleyebilmek için, none parametrik veriler için kullanılan (Hollander, Wolfe \& Chicken, 2013) Spearman Korelasyon analizi yapılmıştır.

\section{Bulgular ve Yorumlar}

Birinci alt problem: Okul yöneticilerinin Duygusal Zekâ ve Kriz yönetimi düzeyleri nedir?

Tablo 5. Duygusal Zekâ Alt Ölçeklerinin Betimsel İstatistikleri

\begin{tabular}{llllll}
\hline Alt Ölçekler & $\begin{array}{l}\text { Madde } \\
\text { sayısı }\end{array}$ & $\bar{X}$ & S.S. & Min. & Max. \\
\hline İyimserlik & 17 & 66.72 & 6.99 & 28.00 & 85.00 \\
\hline
\end{tabular}




\begin{tabular}{llllll}
\hline Duygulardan Faydalanma & 6 & 16.36 & 3.85 & 6.00 & 30.00 \\
\hline Duyguların İfadesi & 14 & 34.90 & 7.13 & 21.00 & 66.00 \\
\hline
\end{tabular}

Tablo 5'te görüldüğü gibi Duygusal Zeka "İyimserlik alt ölçeğinin" aritmetik ortalaması orta düzeydedir ( $\bar{X}=66.72$, ss=6.99). "Duygulardan faydalanma" orta düzeyde $(\bar{X}=16.36, \mathrm{ss}=3.85)$, "Duyguların ifadesi" boyutunda yine orta düzydedir $(\bar{X}=34.90, \mathrm{ss}=7.13)$.

Tablo 6. Kriz yönetimi Alt Ölçeklerinin Betimsel İstatistikleri

\begin{tabular}{llllll}
\hline Alt Ölçekler & $\begin{array}{l}\text { Madde } \\
\text { sayısı }\end{array}$ & $\boldsymbol{X}$ & S.S. & Min. & Max. \\
\hline Kriz öncesi yönetim & 20 & 63.56 & 5.37 & 37.00 & 93.00 \\
\hline Kriz anı yönetim & 33 & 117.25 & 8.69 & 87.00 & 156.00 \\
\hline Kriz sonrası yönetim & 19 & 68.60 & 7.53 & 38.00 & 90.00 \\
\hline
\end{tabular}

Tablo 6'da görüldüğü gibi "Kriz öncesi yönetim" alt boyutunda aritmetik ortalama yüksek düzeyde $(\bar{X}=63.56$, ss= 5.37), "Kriz anı yönetim" alt boyutunda $(\bar{X}=117.25$, ss=8.69) ve "Kriz sonrası yönetim" alt boyutunda yüksek düzeydedir $(\bar{X}=68.60$, ss=7.53).

İkinci alt problem: Okul yöneticilerinin Duygusal Zekâ ve Kriz yönetimi düzeyleri cinsiyete, yöneticilik görevine, yaşa, kıdeme, okul türüne göre farklılaşmakta mıdır?

Tablo 7. Okul Yöneticilerin Duygusal Zekâ Alt Ölçeklerinin Cinsiyete Göre Mann Whitney U Testi Sonuçları

\begin{tabular}{lllllll}
\hline Alt ölçekler & Cinsiyet & $\mathbf{N}$ & $\begin{array}{l}\text { Sira } \\
\text { ortalaması }\end{array}$ & $\begin{array}{l}\text { Sira } \\
\text { toplamı }\end{array}$ & U & p \\
\hline İyimserlik & Kadın & 111 & 272.68 & 30268.00 & $15353.00^{*}$ & .000 \\
& Erkek & 355 & 221.25 & 78543.00 & & .527 \\
\hline Duygulardan & Kadın & 111 & 226.47 & 25138.00 & 18922.00 & \\
faydalanma & Erkek & 355 & 235.70 & 83672.00 & & .229 \\
\hline Duyguların ifadesi & Kadın & 111 & 220.11 & 24432.00 & 18216.00 & \\
& Erkek & 355 & 237.69 & 84379.00 & & \\
\hline
\end{tabular}

Tablo 7'de görüldüğü gibi Okul Yöneticilerinin Duygusal Zekâ alt ölçeklerinden “İyimserlik Ölçeği" puanları cinsiyete göre anlamlı farklılıklar göstermektedir (U=15353.00, p<.01). Sıra ortalamaları dikkate alındığında kadın yöneticilerin iyimserlik ölçeği puanları erkek yöneticilerden yüksek olduğu görülmektedir. Okul Yöneticilerinin Duygusal Zekâ alt ölçeklerinden "Duygulardan Faydalanma Ölçeği”" puanları cinsiyete göre anlamlı farklılıklar göstermemektedir (U=18922.00, p>.05). Okul Yöneticilerinin Duygusal Zekâ alt ölçeklerinden "Duyguların İfadesi Ölçeği" puanları cinsiyete göre anlamlı farklılıklar göstermemektedir $(\mathrm{U}=18922.00, \mathrm{p}>.05)$.

Tablo 8. Okul Yöneticilerin Duygusal Zekâ Alt Ölçeklerinin Yöneticilik Görevine Göre Mann Whitney U Testi Sonuçları

\begin{tabular}{lllllll}
\hline Alt ölçekler & $\begin{array}{l}\text { Yöneticilik } \\
\text { Görevi }\end{array}$ & $\mathbf{N}$ & $\begin{array}{l}\text { Sira } \\
\text { ortalaması }\end{array}$ & $\begin{array}{l}\text { S1ra } \\
\text { toplamı }\end{array}$ & U & p \\
\hline İyimserlik & Müdür & 109 & 227.79 & 24829.00 & 18834.00 & .613 \\
& Müdür Yrd. & 357 & 235.24 & 83982.00 & & \\
\hline Duygulardan & Müdür & 109 & 239.24 & 26077.50 & 18830.50 & .610 \\
faydalanma & Müdür Yrd. & 357 & 231.75 & 82733.50 & & \\
\hline Duyguların & Müdür & 109 & 223.14 & 24322.50 & 18327.50 & .358 \\
ifadesi & Müdür Yrd. & 357 & 236.66 & 84488.50 & & \\
\hline
\end{tabular}


Tablo 8'de görüldügü gibi Okul Yöneticilerinin Duygusal Zekâ alt ölçeklerinden “İyimserlik Ölçeği" puanları yöneticilik görevine göre anlamlı farklılıklar göstermemektedir ( $U=18834.00$, $\mathrm{p}>.05)$.

Tablo 9. Okul Yöneticilerin Duygusal Zekâ Alt Ölçeği Puanlarının Yaşa Göre Kruskal Wallis Testi Sonuçları

\begin{tabular}{|c|c|c|c|c|c|c|c|}
\hline Alt ölçekler & Yaş & $\mathbf{N}$ & $\begin{array}{l}\text { Sira } \\
\text { ortalamas1 }\end{array}$ & sd & Ki kare & $p$ & $\begin{array}{l}\text { Anlamli } \\
\text { fark }\end{array}$ \\
\hline \multirow{4}{*}{ İyimserlik } & A. $20-30$ & 58 & 258.75 & & & & \\
\hline & B.31-40 & 185 & 222.43 & 3 & 3.58 & .310 & \\
\hline & C. $41-50$ & 165 & 233.70 & & & & \\
\hline & D.51 ve üstü & 58 & 242.99 & & & & \\
\hline \multirow{4}{*}{$\begin{array}{l}\text { Duygulardan } \\
\text { faydalanma }\end{array}$} & A.20-30 & 58 & 209.92 & & & & \\
\hline & B.31-40 & 185 & 231.13 & & & & \\
\hline & C. $41-50$ & 165 & 229.52 & 3 & $7.80^{*}$ & .049 & D-A \\
\hline & D.51 ve üstü & 58 & 275.97 & & & & \\
\hline \multirow{4}{*}{$\begin{array}{l}\text { Duyguların } \\
\text { ifadesi }\end{array}$} & A.20-30 & 58 & 232.28 & & & & \\
\hline & B.31-40 & 185 & 224.27 & & & & \\
\hline & C.41-50 & 165 & 236.51 & 3 & 2.52 & .471 & \\
\hline & D.51 ve üstü & 58 & 255.60 & & & & \\
\hline
\end{tabular}

Tablo 9'da görüldügü gibi Okul Yöneticilerinin Duygusal Zekâ alt ölçeklerinden “İyimserlik Ölçeği" puanları yaşa göre anlamlı farklılıklar göstermemektedir $\left(x^{2}=3.58, s d=3, n=466, p>.05\right)$. Okul Yöneticilerinin Duygusal Zekâ alt ölçeklerinden "Duygulardan Faydalanma Ölçeği" puanları yaşa göre anlamlı farklılıklar göstermektedir $\left(x^{2}=7.80, \mathrm{sd}=3, \mathrm{n}=466, \mathrm{p}<.05\right)$. Gruplar arasındaki farkın hangileri arasında olduğunu ortaya koymak amaciyla Mann Whitney U testi yapılmış elde edilen bulgulara göre 51 ve üstü yaşa sahip olanların 20-30 yaşta olanlara göre duygulardan faydalanma ölçeği puanları anlamlı bir şekilde daha yüksek çıkmıştır.

Tablo 10. Okul Yöneticilerin Duygusal Zekâ Alt Ölçeği Puanlarının Kıdeme Göre Kruskal Wallis Testi Sonuçları

\begin{tabular}{lllllll}
\hline Alt ölçekler & Kidem (yıl) & $\mathbf{N}$ & $\begin{array}{l}\text { Sira } \\
\text { ortalaması }\end{array}$ & sd & Ki kare & p \\
\hline & $0-5$ & 36 & 271.76 & & & \\
İyimserlik & $6-10$ & 98 & 235.17 & & & \\
& $11-15$ & 130 & 232.16 & 4 & 4.59 & .333 \\
& $16-20$ & 104 & 216.96 & & & \\
& 21 ve üstü & 98 & 237.11 & & & \\
\hline & $0-5$ & 36 & 231.78 & & & \\
Duygulardan faydalanma & $6-10$ & 98 & 217.24 & & & \\
& $11-15$ & 130 & 224.31 & 4 & 6.62 & .157 \\
& $16-20$ & 104 & 233.62 & & & \\
& 21 ve üstü & 98 & 262.45 & & & \\
Duyguların ifadesi & $0-5$ & 36 & 235.88 & & & \\
& $6-10$ & 98 & 203.74 & & & \\
& $11-15$ & 130 & 231.95 & 4 & 7.53 & .110 \\
& $16-20$ & 104 & 244.43 & & & \\
\hline
\end{tabular}


Tablo 10' da görüldügüü gibi Okul Yöneticilerinin Duygusal Zekâ alt ölçeklerinden “İyimserlik Ölçeği" puanları kıdeme göre anlamlı farklılıklar göstermemektedir ( $x^{2}=4.59$, sd=4, p>.05).

Tablo 11. Okul Yöneticilerin Duygusal Zekâ Alt Ölçeği Puanlarının Eğitim Kademesine Göre Kruskal Wallis Testi Sonuçları

\begin{tabular}{lllllll}
\hline Alt ölçekler & Eğitim Kademesi & N & Sira ortalaması & sd & Ki kare & p \\
\hline \multirow{2}{*}{ İyimserlik } & İlkokul & 161 & 239.39 & & & \\
& Ortaokul & 168 & 223.82 & 2 & 1.37 & .505 \\
& Lise & 137 & 238.45 & & & \\
\hline \multirow{2}{*}{$\begin{array}{l}\text { Duygulardan } \\
\text { faydalanma }\end{array}$} & İlkokul & 161 & 223.03 & & & \\
& Ortaokul & 168 & 235.54 & 2 & 1.75 & .417 \\
& Lise & 137 & 243.30 & & & \\
\multirow{2}{*}{ Duyguların ifadesi } & İlkokul & 161 & 226.00 & & & \\
& Ortaokul & 168 & 239.93 & 2 & .891 & .640 \\
& Lise & 137 & 234.42 & & & \\
\hline
\end{tabular}

Tablo 11'de görüldüğü gibi Okul Yöneticilerinin Duygusal Zekâ alt ölçeklerinden “İyimserlik Ölçeği" puanları eğitim kademesine göre anlamlı farklılıklar göstermemektedir $\left(\mathrm{x}^{2}=1.37, \mathrm{sd}=2\right.$, $\mathrm{p}>$.05).

Tablo 12. Okul Yöneticilerin Kriz Yönetimi Alt Ölçeklerinin Cinsiyete Göre Mann Whitney U Testi Sonuçları

\begin{tabular}{lllllll}
\hline Alt ölçekler & Cinsiyet & $\mathbf{N}$ & $\begin{array}{l}\text { Sıra } \\
\text { ortalaması }\end{array}$ & Sıra toplamı & U & p \\
\hline \multirow{2}{*}{ Kriz öncesi } & Kadın & 111 & 215.41 & 23910.00 & 17694.00 & .104 \\
& Erkek & 355 & 239.16 & 84901.00 & & \\
\hline \multirow{2}{*}{ Kriz anı } & Kadın & 111 & 255.12 & 28318.50 & $17302.50^{*}$ & .049 \\
& Erkek & 355 & 226.74 & 80492.50 & & \\
\hline \multirow{2}{*}{ Kriz sonrası } & Kadın & 111 & 234.44 & 26023.00 & 19598.00 & .933 \\
& Erkek & 355 & 233.21 & 82788.00 & & \\
\hline
\end{tabular}

Tablo 12'de görüldüğü gibi Okul Yöneticilerinin Kriz yönetimi alt ölçeklerinden “Kriz Anı Ölçeği” puanları cinsiyete göre anlamlı farklılıklar göstermektedir (U=17302.50, p<.05). Sıra ortalamaları dikkate alındığında kadın yöneticilerin kriz anı ölçeği puanları erkek yöneticilerden yüksek olduğu görülmektedir. Okul Yöneticilerinin Kriz yönetimi alt ölçeklerinden "Kriz Sonrası Ölçeği" puanları cinsiyete göre anlamlı farklılıklar göstermemektedir ( $\mathrm{U}=19598.00, \mathrm{p}>.05)$.

Tablo 13. Okul Yöneticilerin Kriz Yönetimi Alt Ölçeklerinin Yöneticilik Görevine Göre Mann Whitney U Testi Sonuçları

\begin{tabular}{lllllll}
\hline Alt ölçekler & $\begin{array}{l}\text { Yöneticilik } \\
\text { Görevi }\end{array}$ & $\mathbf{N}$ & $\begin{array}{l}\text { Sıra } \\
\text { ortalamas1 }\end{array}$ & $\begin{array}{l}\text { S1ra } \\
\text { toplamı }\end{array}$ & U & p \\
\hline Kriz öncesi & Müdür & 109 & 260.03 & 28343.00 & $16565.00^{*}$ & .019 \\
& Müdür Yrd. & 357 & 225.40 & 80468.00 & & \\
\hline Kriz anı & Müdür & 109 & 245.89 & 26801.50 & 17106.50 & .272 \\
& Müdür Yrd. & 357 & 229.72 & 82009.50 & & \\
\hline Kriz sonrası & Müdür & 109 & 248.24 & 27058.50 & 17849.50 & .191 \\
& Müdür Yrd. & 357 & 229.00 & 81752.50 & & \\
\hline
\end{tabular}

Tablo 13'te görüldüğü gibi Okul Yöneticilerinin Kriz yönetimi alt ölçeklerinden “Kriz Öncesi Ölçeği" puanları yöneticilik görevlerine göre anlamlı farklılıklar göstermektedir ( $U=16565.00$, 
p<.05). Sıra ortalamaları dikkate alındığında müdürlerin kriz öncesi ölçeği puanları müdür yardımcılarından yüksek olduğu görülmektedir. Bu durum okul yöneticilerinin kriz öncesi kriz yönetimi konusunda müdür yardımcılarından daha başarılı olduğunu ortaya koymaktadır.

Tablo 14. Okul Yöneticilerin Kriz Yönetimi Alt Ölçeği Puanlarının Yaşa Göre Kruskal Wallis Testi Sonuçları

\begin{tabular}{|c|c|c|c|c|c|c|c|}
\hline Alt ölçekler & Yaş & $\mathbf{N}$ & $\begin{array}{l}\text { Sira } \\
\text { ortalamas1 }\end{array}$ & sd & $\begin{array}{l}\text { Ki } \\
\text { kare }\end{array}$ & $p$ & $\begin{array}{l}\text { Anlamlı } \\
\text { fark }\end{array}$ \\
\hline \multirow{4}{*}{ Kriz öncesi } & A. $20-30$ & 58 & 240.97 & \multirow{4}{*}{3} & \multirow{4}{*}{4.39} & \multirow{4}{*}{.549} & \\
\hline & B.31-40 & 185 & 229.21 & & & & \\
\hline & C. $41-50$ & 165 & 224.46 & & & & \\
\hline & D.51 ve üstü & 58 & 265.44 & & & & \\
\hline \multirow{4}{*}{ Kriz anı } & A.20-30 & 58 & 248.66 & \multirow{4}{*}{3} & \multirow{4}{*}{7.93} & \multirow{4}{*}{.011} & \multirow{4}{*}{ D-B } \\
\hline & B.31-40 & 185 & 221.87 & & & & \\
\hline & C. $41-50$ & 165 & 226.78 & & & & \\
\hline & D.51 ve üstü & 58 & 274.56 & & & & \\
\hline \multirow{4}{*}{ Kriz sonrası } & A.20-30 & 58 & 240.57 & \multirow{4}{*}{3} & \multirow{4}{*}{1.28} & \multirow{4}{*}{.891} & \\
\hline & B.31-40 & 185 & 224.92 & & & & \\
\hline & C. $41-50$ & 165 & 237.95 & & & & \\
\hline & D.51 ve üstü & 58 & 241.12 & & & & \\
\hline
\end{tabular}

Tablo 14'te görüldüğü gibi Okul Yöneticilerinin Kriz yönetimi alt ölçeklerinden “Kriz Anı Ölçeği" puanları yöneticilerin yaşlarına göre anlamlı farklılıklar göstermektedir $\left(x^{2}=7.93, s d=3\right.$, $\mathrm{p}<.05)$. Gruplar arasındaki farkın hangileri arasında olduğunu ortaya koymak amacıyla Mann Whitney U testi yapılmış elde edilen bulgulara göre 51 ve üstü yaşa sahip olanların 31-40 yaşta olanlara göre kriz anında kriz yönetimini daha başarılı bir şekilde gerçekleştirdikleri belirtilebilir.

Tablo 15. Okul Yöneticilerin Kriz Yönetimi Alt Ölçeği Puanlarının Kıdeme Göre Kruskal Wallis Testi Sonuçları

\begin{tabular}{lllllll}
\hline Alt ölçekler & Kidem $(\mathbf{y} \mathbf{l})$ & $\mathbf{N}$ & Sira ortalamas1 & sd & Ki kare & p \\
\hline \multirow{4}{*}{ Kriz öncesi } & $0-5$ & 36 & 249.13 & & & \\
& $6-10$ & 98 & 224.92 & & & \\
& $11-15$ & 130 & 227.47 & 4 & 1.54 & .819 \\
& $16-20$ & 104 & 236.10 & & & \\
Kriz anı & 21 ve üstü & 98 & 241.58 & & & \\
& $0-5$ & 36 & 227.76 & & & \\
& $6-10$ & 98 & 235.74 & & & \\
& $11-15$ & 130 & 224.18 & 4 & 1.90 & .753 \\
Kriz sonrasi & $16-20$ & 104 & 231.24 & & & \\
& 21 ve üstü & 98 & 248.13 & & & \\
& $0-5$ & 36 & 246.56 & & & \\
& $6-10$ & 98 & 219.25 & & & \\
& $11-15$ & 130 & 246.08 & 4 & 2.76 & \\
\hline
\end{tabular}


Tablo 15’te görüldüğü gibi Okul Yöneticilerinin Kriz yönetimi alt ölçeklerinden “Kriz Öncesi Ölçeği" puanları yöneticilerin kıdemlerine göre anlamlı farklılıklar göstermemektedir $\left(x^{2}=1.54, \mathrm{sd}=4, \mathrm{p}>.05\right)$.

Tablo 16. Okul Yöneticilerin Kriz Yönetimi Alt Ölçeği Puanlarının Eğitim Kademesine Göre Kruskal Wallis Testi Sonuçları

\begin{tabular}{llllllll}
\hline Alt ölçekler & $\begin{array}{l}\text { Eğitim } \\
\text { Kademesi }\end{array}$ & N & Sira ortalaması & sd & Ki kare & p & $\begin{array}{l}\text { Anlamli } \\
\text { Fark }\end{array}$ \\
\hline \multirow{3}{*}{ Kriz öncesi } & A.İlkokul & 161 & 248.20 & & & & \\
& B.Ortaokul & 168 & 228.19 & 2 & 3.07 & .216 & \\
& C:Lise & 137 & 222.73 & & & & \\
\multirow{3}{*}{ Kriz anı } & A.İlkokul & 161 & 244.03 & & & & \\
& B.Ortaokul & 168 & 224.41 & 2 & 1.76 & .414 & \\
& C.Lise & 137 & 232.27 & & & & \\
\multirow{2}{*}{ Kriz sonrası } & A.Illkokul & 161 & 255.61 & & & & \\
& B.Ortaokul & 168 & 220.89 & 2 & 6.67 & .036 & A-B \\
& C.Lise & 137 & 222.99 & & & & \\
\hline
\end{tabular}

Tablo 16’ da görüldüğü gibi Okul Yöneticilerinin Kriz yönetimi alt ölçeklerinden “Kriz Sonrası Ölçeği" puanları eğitim kademesi değişkeninegöre anlamlı farklılıklar göstermektedir $\left(\mathrm{x}^{2}=(\mathrm{sd}=2, \mathrm{n}=466)=6.67, \mathrm{p}>.05\right)$. Gruplar arasındaki farkın hangileri arasında olduğunu ortaya koymak amacıyla Mann Whitney U testi yapılmış elde edilen bulgulara göre ilkokulda görev yapan okul yöneticilerinin ortaokulda görev yapan okul yöneticilerine göre kriz sonrası kriz yönetiminde daha başarılı olmaktadırlar.

Üçüncü alt problem: Okul yöneticilerinin Duygusal Zekâ ve Kriz yönetimi düzeyleri arasında anlamlı bir ilişki var mıdır?

Tablo 17. Kriz Yönetimi ve Duygusal Zekâ Alt Ölçek Puanları Arasındaki Spearman's Rank Order Korelasyon Testi Sonuçları

\begin{tabular}{lcccc}
\hline Değişkenler & \multicolumn{3}{c}{ Kriz yönetimi } \\
\hline Duygusal zekâ & & Kriz öncesi & Kriz anı & Kriz sonrası \\
\hline \multirow{3}{*}{ İyimserlik } & $\mathrm{r}$ & .078 & $.308^{* *}$ & $.330^{* *}$ \\
\cline { 2 - 5 } & $\mathrm{N}$ & 466 & 466 & 466 \\
\cline { 2 - 5 } & $\mathrm{p}$ & .093 & .000 & .000 \\
\hline \multirow{3}{*}{ Duygulardan faydalanma } & $\mathrm{r}$ & $.169^{* *}$ & .001 & $.119^{*}$ \\
\cline { 2 - 5 } & $\mathrm{N}$ & 466 & 466 & 466 \\
\cline { 2 - 5 } & $\mathrm{p}$ & .000 & .982 & .010 \\
\hline \multirow{3}{*}{ Duyguların ifadesi } & $\mathrm{r}$ & $.134^{* *}$ & .80 & -.034 \\
\cline { 2 - 5 } & $\mathrm{N}$ & 466 & 466 & 466 \\
\cline { 2 - 5 } & $\mathrm{p}$ & .004 & .083 & .463 \\
\hline
\end{tabular}

${ }^{* *} \mathrm{p}<0,01,{ }^{*} \mathrm{p}<0,05$

Tablo 17' de görüldüğü gibi duygusal zekâ alt ölçeklerinden iyimserlik ölçeği puanları ile kriz anı $(r=.31, p<.01)$ ve kriz sonrası $(r=.33, p<.01)$ ölçek puanları arasında pozitif yönde ilişkiler bulunmuştur. İyimserlik ölçeği puanları ile kriz öncesi $(r=.08, p>.05)$ ölçek puanları arasında bir ilişki bulunmamıştır. Duygusal zekâ alt ölçeklerinden duygulardan faydalanma ölçeği puanları ile kriz öncesi $(r=.17, p<.01)$ ve kriz sonrası $(r=.12, p<.05)$ ölçek puanları arasında düşük ancak anlamlı düzeyde ilişkiler bulunmaktadır. Bununla birlikte duygulardan faydalanma ve kriz anı ölçek puanları arasında $(r=.001, p>.05)$ anlamlı bir ilişki 
bulunmamıştır. Duygusal zekâ alt ölçeklerinden duyguların ifadesi ölçeği puanları ile kriz öncesi ölçek puanları arasında $(r=.13, p<.01)$ pozitif yönde anlamlı bir ilişki bulunmaktadır. Bununla birlikte duyguların ifadesi ölçek puanları ile kriz anı $(r=.008, p>.05)$ ve kriz sonrası $(r=-, 03, p>.05)$ ölçek puanları arasındaki ilişki anlamlı değildir.

\section{Sonuç-Tartışma}

Araştırmaya katılan okul yöneticilerinin Duygusal Zekâ alt ölçeklerinden "İyimserlik Ölçeği” puanları cinsiyete göre anlamlı farklılıklar göstermektedir. Buna göre ortalamaları dikkate alındığında kadın yöneticilerin iyimserlik ölçeği puanları erkek yöneticilerden yüksek olduğu görülmektedir. Okul yöneticilerinin Duygusal Zekâ alt ölçeklerinden "Duygulardan Faydalanma Ölçeği" ve "Duyguların İfadesi Ölçeği" puanları cinsiyet değişkenine göre anlamlı farklılıklar göstermemektedir. İyimserlik boyutunun kadınlarda erkeklere göre yüksek çıkması; kadınların empati kurabildiği, iyimser düşündüğü, olumlu olumsuz durumları erkeklere göre daha rahat fark edebildiği anlamında yorumlanabilir. Araştırmalara bakıldığında Mayer, Caruso, Salovey (1999), Caputi, Chan, Ciarrochi (2000), Göçet (2006) gibi kadınların duygusal zekâ boyutlarının erkeklerden yüksek olduğunu gösteren birçok araştırma bulunmaktadır. Yine literatür içinde Bar-on ve arkadaşları (2000), Akeren (2006), Babaoğlan (2010) yaptığı araştırmalar incelendiğinde kadın yöneticiler ile erkek yöneticiler arasında duygusal zekâ boyutları arasında bir fark yoktur diyen farklı araştırmalarda mevcuttur.

Araştırmaya katılan okul yöneticilerinin Duygusal Zekâ alt ölçeklerinin alt puanları yöneticilik görevi değişkenine göre anlamlı farklılıklar bulunmamıştır. Babaoğlan (2010), yapmış olduğu araştırmada bu sonucu desteklemektedir.

Araştırmaya katılan okul yöneticilerinin Duygusal Zekâ alt ölçeklerinden “Duygulardan Faydalanma Ölçeği" puanları yaş değişkenine göre anlamlı farklılıklar göstermektedir. Buna göre 51 ve üstü yaşa sahip okul yöneticilerinin 20-30 yaşta olanlara göre duygulardan faydalanma ölçeği puanlarının daha yüksek olduğu sonucuna ulaşılmıştır. Bu sonuçla yaş ilerledikçe yöneticinin, mesleğe yeni başlayan meslektaşlarına göre okuldaki yeni olasılıkların farkına varılmasını kolaylaştırdığı, birlikte çalıştı̆̆ı personelin duygularını tanıyıp güven ve huzur ortamı içinde olduklarını onlara hissettirdiği, personelinin duygularınıdaha iyi yönetebildiği ve kendi duygularını tanıyarak yaşayabileceği olumsuz duyguları ve güdüleri kontrol altına daha rahat tutabilmesi olarak yorumlanabilir. Mayer, Caruso, Salovey (1999), Bar-on ve arkadaşları (2000), yaptıkları çalışmalarda yaş arttıkça duygusal zekânın da yükseleceği sonucuna ulaşmışlardır. Akeren (2006) ve Babaoğlan (2010) yaptığı araştırmalarda yöneticilerin duygusal zekâ alt ölçeklerinde yaş değişkenine göre bir fark bulamamıştır.

Araştırmaya katılan okul yöneticilerinin Duygusal Zekâ alt ölçeklerinin alt puanları mesleki kıdem değişkenine göre anlamlı farklılıklar bulunmamıştır. Akeren (2006), yöneticilerin duygusal zekâ alt ölçeklerinde kıdem değişkenine göre bir fark bulamamıştır. Araştırmaya katılan okul yöneticilerinin Duygusal Zekâ alt ölçeklerinin alt puanları eğitim kademesi değişkenine göre anlamlı farklılıklar bulunmamıştır. Babaoğlan (2010), duygusal zekâ alt ölçeklerinde eğitim kademesi değişkenine göre ilköğretim okullarındaki yöneticilerinin ortaöğretim okullarındaki yöneticilere göre duygusal zekâ puanlarını daha yüksek bulmuştur.

Araştırmaya katılan okul yöneticilerinin Kriz yönetimi alt ölçeklerinden "Kriz Anı Ölçeği” puanları cinsiyet değişkenine göre anlamlı farklılıklar göstermektedir. Buna göre ortalamaları dikkate alındığında kadın yöneticilerin kriz anı ölçeği puanları erkek yöneticilerden yüksektir. 
Okul yöneticilerinin Kriz yönetimi alt ölçeklerinden “Kriz Öncesi Ölçeği” ve "Kriz Sonrası Ölçeği" puanları cinsiyete değişkenine göre anlamlı farklılıklar göstermemektedir. Kadın yöneticilerin kriz anı ölçeği puanlarının erkek yöneticilerden yüksek çıkması, kadın yöneticilerin her an yaşanabilecek bir krize hazır oldukları, kriz anı yönetimde kendilerini hazır tuttukları şeklinde yorumlanabilir. Şahin (2014), yaptığı araştırmasında kadın öğretmenlerin kriz yönetimi algılarını erkek öğretmenlerden yüksek bulmuştur. Özsezer (2014), cinsiyet değişkenine göre okul yöneticilerinin kriz yönetimi becerileri "kriz anı" ve "kriz sonrası" boyutlarında erkeklerde, bayanlara göre anlamlı derecede yeterli bulunmuştur. Maya (2014), Ulutaş (2010), Wheeler (2002, Akt. Ocak, 2006), yöneticilerin kriz yönetimi alt ölçeklerinde cinsiyete göre anlamlı bir fark bulamamıştır.

Araştırmaya katılan okul yöneticilerinin Kriz yönetimi alt ölçeklerinden “Kriz Öncesi Ölçeği” puanları yöneticilik görevi değişkenine göre anlamlı farklılıklar göstermektedir. Buna göre ortalamaları dikkate alındığında müdürlerin kriz öncesi ölçeği puanları müdür yardımcılarından yüksektir. Bu durum okul müdürlerinin kriz öncesi kriz yönetimi konusunda müdür yardımcılarından daha başarılı olduğu ve kendilerini kriz yönetimi ile ilgili gerekli hazırlıkları yapmak konusunda sorumlu hissettiklerini ortaya koymaktadır. Okul yöneticilerinin Kriz yönetimi alt ölçeklerinden "Kriz Anı Ölçeği" ve "Kriz Sonrası Ölçeği" puanları yöneticilik görevi değişkenine göre anlamlı farklılıklar göstermemektedir. Sayın (2008)'ın, yaptığı çalışmada da yöneticilik görevi değişkenine göre benzer farklılık bulunmuştur.

Araştırmaya katılan okul yöneticilerinin Kriz yönetimi alt ölçeklerinden "Kriz Anı Ölçeği” puanları yöneticilerin yaş değişkenine göre anlamlı farklılıklar göstermektedir. Buna göre bulgular incelendiğinde 51 ve üstü yaşa sahip okul yöneticilerinin 31-40 yaşta olanlara göre kriz anında kriz yönetimini daha başarılı bir şekilde gerçekleştirmektedirler. Okul yöneticilerinin Kriz yönetimi alt ölçeklerinden "Kriz Öncesi Ölçeği" ve "Kriz Sonrası Ölçeği" puanları yaş değişkenine göre anlamlı farklılıklar göstermemektedir. Bu sonuç yaşça tecrübeli okul yöneticilerinin kriz yaşanırken kriz yönetiminde kendi tecrübelerinden faydalanarak krizleri kontrol altına aldıkları şeklinde yorumlanabilir. Sayın (2008), Yıldız (2014) yöneticilerin yaşının arttıkça kriz yönetimi becerilerinin arttığı sonuçlarını elde etmişlerdir. Şahin (2014), 41-45 yaşlarındaki öğretmenlerin kriz yönetimi düşünceleri, 22-30 yaşlarındaki, 36-40 yaşlarındaki ve 31-35 yaşlarındaki öğretmenlere göre daha yüksektir. Wheeler (2002, Akt. Ocak,2006), Ulutaş (2010), okul yöneticilerinin kriz yönetimi alt ölçeklerinde yaş değişkenine göre anlamlı bir fark bulamamıştır.

Araştırmaya katılan okul yöneticilerinin Kriz yönetimi alt ölçeklerinin alt puanları mesleki kıdem değişkenine göre anlamlı farklılıklar bulunmamıştır. Wheeler (2002, Akt. Ocak,2006), okul yöneticilerinin kriz yönetimi alt ölçeklerinde mesleki kıdem değişkenine göre anlamlı bir fark bulamamıştır. Şahin (2014), 16 yıl ve üstünde kıdemi bulunan öğretmenlerin kriz yönetimi düşünceleri, 11-15 yıl ve 6-10 yıl kıdemi bulunan öğretmenlere göre yüksek bulunmuştur. Ayyürek (2014), kıdeme göre okulda ilk defa göreve başlayan öğretmenlerin kriz öncesi hazırlanma ve planlama aşamalarıyla ilgili fikirleri 5 yıldan fazla kıdeme sahip öğretmenlerden daha olumsuz bulunmuştur. Maya (2014), Sayın (2008), Yıldız (2014), ise okul yöneticilerinin mesleki kıdemi arttıkça kriz yönetimi becerilerinin arttığı sonuçlarını elde etmişlerdir.

Araştırmaya katılan okul yöneticilerinin Kriz yönetimi alt ölçeklerinden "Kriz Sonrası Ölçeği" puanları eğitim kademesi değişkenine göre anlamlı farklılıklar göstermektedir. Buna göre 
ortalamaları dikkate alındığında ilkokulda görev yapan okul yöneticilerinin ortaokulda görev yapan okul yöneticilerine göre kriz sonrası kriz yönetiminde daha başarılıdır. Okul yöneticilerinin Kriz yönetimi alt ölçeklerinden "Kriz Öncesi Ölçeği" ve "Kriz Anı Ölçeği" puanları eğitim kademesi değişkenine göre anlamlı farklılıklar göstermemektedir. Küçük çocukların eğitim gördüğü ilkokullardaki okul yöneticileri okul ortamında gerekli güven ve huzur ortamını sağlamakta baş sorumlu kişilerdir. O yüzden kriz sonrası gerçekleştirilecek iyileştirme ve öğrenme basamaklarında gerekli tecrübeye sahip olmaları beklenebilir bir durum olarak yorumlanabilir. Özsezer (2014), eğitim kademesi değişkenine göre okul yöneticilerinin kriz yönetimi becerileri "kriz anı" ve "kriz sonrası" boyutlarında genel lisedeki öğretmenler, meslek lisesindeki öğretmenlere göre anlamlı derecede yeterli bulunmuştur.

Araştırmaya katılan okul yöneticilerinin duygusal zekâ alt ölçeklerinden iyimserlik ölçeği puanları ile kriz yönetimi alt ölçeklerinden kriz anı ve kriz sonrası yönetim alt ölçek puanları arasında pozitif yönde ilişkiler bulunmuştur. İyimserlik ölçeği puanları ile kriz öncesi ölçek puanları arasında ise bir ilişki bulunmamıştır. Buna göre okul yöneticilerinin iyimserlik puanları arttıkça kriz anı ve kriz sonrası puanları da artmaktadır. Kriz anı ve kriz sonrasında yaşanabilecek olumsuzlukların giderilebilmesi, krizden fayda sağlanabilmesi, kriz ile ilgili değerlendirmenin yapılabilmesi, olumlu ve olumsuz sonuçların farkında olunması açısından iyimserlik boyutunun yüksek olması kriz yönetimi açısından olumlu bir sonuç olarak kabul edilebilir.

Araştırmaya katılan okul yöneticilerinin duygusal zekâ alt ölçeklerinden duygulardan faydalanma ölçeği puanları ile kriz yönetimi alt ölçeklerinden kriz öncesi ve kriz sonrası yönetim alt ölçek puanları arasında düşük ancak anlamlı yönde ilişkiler bulunmuştur. Duygulardan faydalanma puanları ile kriz anı ölçek puanları arasında ise bir ilişki bulunmamıştır. Buna göre okul yöneticilerininduygulardan faydalanma puanları arttıkça kriz öncesi ve kriz sonrası puanları düşükte olsa artmaktadır. Kriz öncesi ve sonrası dönemlerinde kriz ile ilgili mesajları doğru algılamak önemlidir. Okul yöneticileri, kriz öncesi ve kriz sonrası zamanlarında iletişim problemlerini çözecek önlemler almalıdır. Okul yöneticilerinin bu zamanlarda duygusal ve zihinsel gelişimlerini kullanarak, kurumdaki insanların krize karşı hazırlıklı olmasını sağlamalıdır. Krizden sonra ise dersler çıkartılmasıyla ilgili gereken olumlu duyguları ortaya koyması hem kendisinin hem de çevresindeki insanların duygularından faydalanması etkili kriz yönetiminde yararlı olabilecek tutumlar oalarak kabul edilebilir.

Araştırmaya katılan okul yöneticilerinin duygusal zekâ alt ölçeklerinden duyguların ifadesi ölçeği puanları ile kriz yönetimi alt ölçeklerinden kriz öncesi yönetim alt ölçek puanları arasında pozitif yönde anlamlı bir ilişki bulunmaktadır. Duyguların ifadesi puanları ile kriz anı ve kriz sonrası ölçek puanları arasında ise bir ilişki bulunmamıştır. Buna göre okul yöneticilerinin duygulardan ifadesi puanları arttıkça kriz öncesi puanları artmaktadır. Kriz sinyallerinin alınmaya başlaması ve krizin önlenme çalışmalarının yoğunlaştığı kriz öncesi dönemde doğru iletişim kurmak, ortaya çıkabilecek olumlu ve olumsuz durumları kestirebilmek, kriz ile ilgili oluşabilecek duyguların farkına varıp onları ifade edebilecek ortamların hazırlığını yapmak, yanlış anlamaları önlemek için kriz durumlarıyla ilgili bilgi sahibi olmak kriz yönetiminde başarılı olmaya destek oluşturabilir.

Sonuç olarak; okul yöneticilerinin duygusal zekâları ile kriz yönetimi tutumları arasında pozitif yönde anlamlı bir ilişkinin belirlenmiş olmasının kriz yönetimindeki başarı için önemli olduğu ifade edilebilir. 


\section{Öneriler}

Okullardaki yöneticilerin duygusal zekâ düzeyinin yüksek olması eğitimindeki birçok konuyu direkt olarak etkilediği gibi, bu araştırma sonuçlarına göre kriz yönetimi tutumlarını da etkilediği görülmektedir. Bu konuyla ilgili olarak şu an çalışan okul yöneticilerinin duygusal zekâ düzeylerinin yükseltilmesine yönelik Millî Eğitim Bakanlı̆̆ı bünyesinde hizmet içi eğitimler düzenlenebilir.

Kriz yönetiminde kriz öncesi yönetim ve kriz anı yönetim uygulamalarındaki başarı, krizin başlamadan önüne geçilmesinde ve olumsuz sonuçlar doğurmasına engel olunmasında önemli yer tutmaktadır. Araştırmaya katılan okul yöneticilerinin kriz yönetimindeki kriz sonrası yönetim uygulamalarında kendilerini daha başarılı algıladıkları tespit edilmiştir. Bu sonuçtan dolayı kriz başlamadan önüne geçilmesi ve olumsuz sonuçlar doğurmasına engel olunması amacıyla yönetici seçiminde bu etkenlerin dikkate alınması yararlı olabilir.

Araştırmaya katılan okul yöneticilerinin cinsiyet değişkenine göre kadın yöneticilerin iyimserlik ölçeği puanları erkek yöneticilerden yüksek olduğu görülmektedir. Bunun yanı sıra araştırmaya katılan okul yöneticilerinin cinsiyet değişkenine göre kadın yöneticilerin kriz anı ölçeği puanları erkek yöneticilerden yüksek bulunmuştur. Bu sonuçlar kadın okul yöneticilerinin algılama, empati ve uyum konusunda daha başarılı olduklarını göstermektedir. Ayrıca kriz zamanlarında kadın yöneticilerin, sözel olmayan mesajları, sorunları daha kolay algılayıp, değişen durumlara daha kolay uyum sağlayabildikleri ve yaşanılan krizi kontrol altına almakta daha başarılı oldukları söylenebilir. Tüm bu nedenlerden dolayı okul yönetiminde kadın yöneticilerin sayısının arttırılmasına ve teşvik edilmesine yönelik Millı̂ Eğitim Bakanlığı bünyesindeki atama yönetmeliğinde gerekli düzenlemelerin yapılması önerilebilir.

Araştırmaya katılan okul yöneticilerinin yaş değişkenine göre 51 ve üstü yaşa sahip okul yöneticilerinin 20-30 yaşta olanlara göre duygulardan faydalanma ölçeği puanlarının daha yüksek olduğu sonucuna ulaşılmıştır. Göreve yeni başlayan okul yöneticileri ile ilgili eğitim programlarının verimli olabileceği ve bu okul yöneticilerin duygusal zekâ düzeylerinin yükseltilmesi ile ilgili çalışmalar içerisinde yer almaları sağlanabilir.

Araştırmaya katılan okul yöneticilerinin Kriz yönetiminde yöneticilik görevi_değişkenine göre müdürlerin kriz öncesi ölçeği puanları müdür yardımcılarından yüksek bulunmuştur. Okul içerisinde işlerin yürütülmesi ile ilgili sorumluluk genelde müdür yardımcılarındadır. Müdür yardımcılarının okul içerisinde kriz yönetimi konusunda okul müdürleri ile ortak çalışmalar yapması, okul müdürlerinin tecrübelerini aktarması müdür yardımcılarının bilgi düzeylerini yükseltmesini sağlayabilir.

Araştırmaya katılan okul yöneticilerinin yaş değişkenine göre 51 ve üstü yaşa sahip okul yöneticilerinin 31-40 yaşta olanlara göre kriz anında kriz yönetimini daha başarılı bir şekilde yönettikleri sonucuna ulaşılmıştır. Göreve yeni başlayan okul yöneticileri ile ilgili kriz yönetimi konusunda tecrübeli okul yöneticilerinin eğitimler vermesi ve 31-40 yaşta olan okul yöneticilerin kriz anı kriz yönetimi düzeylerinin yükseltilmesi ile ilgili çalışmalar içerisinde yer almaları sağlanabilir.

Bu araştırma İstanbul ilinin iki ilçesindeki devlet okullarında görevli okul yöneticileri ile sınırlı tutulmuştur. Türkiye genelinde farklı ile ve ilçelerdeki okul yöneticilerine de uygulanarak buradan elde edilen sonuçlarla karşılaştırılabilir. 
Bu araştırma İstanbul ilinin iki ilçesindeki devlet okullarında görevli okul yöneticileri birlikte ele alınarak değerlendirilmiştir. Farklı iki ilçedeki okullarda görevli okul yöneticilerden alınan veriler karşılaştırılarak bu araştırma tekrardan yapılabilir. Bu araştırmaya öğretmenlerin algıları da eklenerek tekrarlanabilir. Gelecekte yapılacak araştırmalarda okul yöneticilerinin kriz yönetimi tutumlarının belirlenmesi için kullanılan tekniklerin yanında nitel yöntemlerden de faydalanılması yararlı olabilir.

\section{KAYNAKÇA}

Akeren, N. (2006). Orta öğretimde görevli yöneticilerin duygusal zekâ düzeyleri ile örgütsel çatışmaları çözümleme stratejileri arasındaki ilişki: İzmir ili örneğgi (Yayımlanmamış Yüksek Lisans Tezi). Ege Üniversitesi, Sosyal Bilimler Enstitüsü, İzmir.

Aksoy, H. H.\& Aksoy, N. (2003). Okullarda Krize Müdahale Planlaması. Ankara Üniversitesi Ĕ̆itim Bilimleri Fakültesi Dergisi,36(1): 37-49.

Albus, J. S. (1991). Outline for a theory of intelligence. IEEE transactions on systems, man, and cybernetics, 21(3), 473-509.

Arbak, Y \& Çakar, U. (2004). Modern Yaklaşımlar Işığında Değişen Duygu-Zekâ İlişkisi ve Duygusal Zekâ. Dokuz Eylül Üniversitesi Sosyal Bilimler Enstitüsü Dergisi, 6(3):23-48.

Asunakutlu, T. Safran, B. Tosun, E. (2003). Kriz yönetimi Üzerine Bir Araştırma, Dokuz Eylül Üniversitesi Sosyal Bilimler Enstitüsü Dergisi, 5(1):141-163.

Ayyürek, O. (2014). Eğitim örgütlerinde kriz yönetimi: Van depremi örneği (Yayınlanmamış Yüksek Lisans Tezi). Yüzüncü Yıl Üniversitesi, Van.

Babaoğlan, E. (2010). Okul Yöneticilerinde Duygusal Zekâ. Ahi Evran Üniversitesi Kırşehir Ĕgitim Fakültesi Dergisi,11(1):119-136.

Bar-On, R. Brown, J. M. Kirkcaldy, B. D. \& Thome, E. P. (2000). Emotional Expression And Implications For Occupational Stress; An Application Of The Emotional Quotient Inventory (EQ-İ). Personality And Individual Differences, 28(6):1107-1118.

Caputi, P. Chan, A. Y. \& Ciarrochi, J. V. (2000). A Critical Evaluation Of The Emotional İntelligence Construct. Personality And Individual Differences, 28(3):539-561.

Çetinkaya, Ö. \& Alparslan, A. M. (2011). Duygusal zekânin iletişim becerileri üzerine etkisi: üniversite öğrencileri üzerinde bir araştirma. Süleyman Demirel Üniversitesi İktisadi ve İdari Bilimler Fakültesi Dergisi, 16(1), 363-377.

Göçet, E. (2006). Üniversite öğrencilerinin duygusal zekâ düzeyleri ile stresle başa çıkma tutumları arasındaki ilişki (Yayınlanmamış Yüksek Lisans Tezi). Sakarya Üniversitesi, Sosyal Bilimler Enstitüsü, Sakarya.

Güllüce, A. Ç. (2006). Mesleki tükenmişlik ve duygusal zekâ arasındaki ilişki: Yöneticiler üzerine bir uygulama (Yayınlanmamış Yüksek Lisans Tezi). Atatürk Üniversitesi, Sosyal Bilimler Enstitüsü, Erzurum.

Hollander, M., Wolfe, D. A., \& Chicken, E. (2013). Nonparametric statistical methods (Vol. 751). John Wiley \& Sons. http://www.acarindex.com/dosyalar/makale/acarindex1423868312.pdf [Erişim:01/01/2018].

Karaköse, T. (2007). Örgütler ve Kriz yönetimi. Akademik Bakış, (13):1-15. 
Karasar, N.(2006). Bilimsel Araştırma Yöntemi. Ankara: Nobel Yayın Dağıtım.

Maya, İ. (2014). Kamu İlkokullarında Yöneticilerin Sergiledikleri Kriz yönetimi Beceri Düzeylerine İlişkin Öğretmen Görüşleri. Çanakkale On Sekiz Mart Üniversitesi Dergileri, Yönetim Bilimleri Dergisi,12(23):209-235.

Mayer, J. D, Caruso, D. R.ve Salovey, P. (1999). Emotional Intelligence Meets Traditional Standards For An Intelligence. Intelligence,27(4):267-298.

Mayer, J. D, Salovey, P. (1990). Emotional Intelligence, Imagination, Cognition, and Personality, 9(3):185-211.

Ocak, Y. (2006). Ortä̈̆gretim okullarında kriz yönetimi: Edirne ili örneği (Yüksek Lisans Tezi). Trakya Üniversitesi, Sosyal Bilimler Enstitüsü, Edirne.

Özsezer, S. (2014). Liselerde kriz yönetimine ilişkin yönetici ve öğretmen görüşleri (Yüksek Lisans Tezi). Uşak Üniversitesi, Sosyal Bilimler Enstitüsü, Uşak.

Öztekin, A. (2006). Ortaöğretim kurumlarında görev yapan yöneticilerin duygusal zekâ becerilerini okul yönetiminde kullanma düzeylerinin değerlendirilmesi: Balıkesir il örneği (Yüksek Lisans Tezi). Balıkesir Üniversitesi, Sosyal Bilimler Enstitüsü, Balıkesir.

Pearson, C. M., \& Clair, J. A. (1998). Reframing crisis management. Academy of management review, 23(1), 59-76.

Salovey, P., \& Mayer, J. D. (2004). Emotional intelligence. In P. Salovey, M. A. Brackett, \& J. D. Mayer (Eds.), Emotional intelligence: Key readings on the Mayer and Salovey model (p. 1-27).

Sayın, N. (2008). Ortaöğretim kurumlarında kriz yönetimi stratejisinin incelenmesi: İstanbul ili örneğ i (Doktora Tezi). Marmara Üniversitesi, Sosyal Bilimler Enstitüsü, İstanbul.

Şahin, Z. (2014). Kriz yönetimi ve psikolojik sermaye arasındaki ilişki (Yüksek Lisans Tezi). Harran Üniversitesi, Sosyal Bilimler Enstitüsü, Şanlıurfa.

Ulutaş, S. (2010). Kriz yönetimi ve dönüşümcü liderlik (Yüksek Lisans Tezi). Dokuz Eylül Üniversitesi, Eğitim Bilimleri Enstitüsü, İzmir.

Yıldız, Ç. (2014). Okul yöneticilerinin kriz yönetimi tutumları ile algılanan örgüt sağlığı arasındaki ilişki: Üsküdar ilçesi örneği (Yayınlanmamış Yüksek Lisans Tezi). Yeditepe Üniversitesi, Sosyal Bilimler Enstitüsü, İstanbul. 